\title{
Article \\ Xenia and Deficit Nitrogen Influence the Iron and Zinc Concentration in the Grains of Hybrid Maize
}

\author{
Sajjad Akhtar ${ }^{1}$, Maryke Labuschagne ${ }^{1}\left(\mathbb{D}\right.$, Gernot Osthoff $^{2}\left(\mathbb{D}\right.$, Kingston Mashingaidze $^{3}$ and Akbar Hossain ${ }^{4, *}$ \\ 1 Department of Plant Sciences, University of the Free State, Bloemfontein 9300, South Africa; \\ akhtarsajjad21@gmail.com (S.A.); labuscm@ufs.ac.za (M.L.) \\ 2 Department of Microbial Biochemical and Food Biotechnology, University of the Free State, \\ Bloemfontein 9300, South Africa; OsthoffG@ufs.ac.za \\ 3 ARC-Grain Cops Institute, Potchefstroom 2520, South Africa; mashingaidzek@arc.agric.za \\ 4 Department of Agronomy, Bangladesh Wheat and Maize Research Institute, Dinajpur 5200, Bangladesh \\ * Correspondence: akbarhossainwrc@gmail.com
}

\section{check for}

updates

Citation: Akhtar, S.; Labuschagne, M.; Osthoff, G.; Mashingaidze, K.; Hossain, A. Xenia and Deficit Nitrogen Influence the Iron and Zinc Concentration in the Grains of Hybrid Maize. Agronomy 2021, 11, 1388. https://doi.org/10.3390/ agronomy 11071388

Academic Editors:

Dominika Średnicka-Tober and Ewelina Hallmann

Received: 27 May 2021

Accepted: 30 June 2021

Published: 9 July 2021

Publisher's Note: MDPI stays neutral with regard to jurisdictional claims in published maps and institutional affiliations.

Copyright: (c) 2021 by the authors. Licensee MDPI, Basel, Switzerland. This article is an open access article distributed under the terms and conditions of the Creative Commons Attribution (CC BY) license (https:// creativecommons.org/licenses/by/ $4.0 /)$.

\begin{abstract}
Xenia is the immediate effect of pollen on seed development after pollination. This study was conducted to investigate xenia's effects on Fe and $\mathrm{Zn}$ concentration in self- and open-pollinated maize seeds. Eighteen maize hybrids derived from parents with varying concentrations of $\mathrm{Fe}$ and $\mathrm{Zn}$ were planted at Potchefstroom, Cedara and Vaalharts in South Africa for two seasons, 2017 and 2018. Open- and self-pollinated seeds were compared. Self-pollination of five selected healthy maize hybrids of uniform height from each plot was performed. Fe, $\mathrm{Zn}$ and phytic acid (Pa) analysis was conducted on self -and open-pollinated maize seeds, and the molar ratios of $\mathrm{Fe}$ and $\mathrm{Zn}$ to Pa were also calculated to assess the bioavailability of Fe and $\mathrm{Zn}$. The ranges of $\mathrm{Fe}, \mathrm{Zn}$ and $\mathrm{Pa}$, and the molar ratios of Fe and $\mathrm{Zn}$ to Pa in selfpollinated maize seeds were $15.93-21.36 \mathrm{mg} \mathrm{kg}^{-1}, 18.50-24.34 \mathrm{mg} \mathrm{kg}^{-1}, 4.63-5.84 \mathrm{mg} \mathrm{g}^{-1}, 21.97-31.22$ and 23.53-30.16 under high $\mathrm{N}$, and 12.76-19.29 $\mathrm{mg} \mathrm{kg}^{-1}, 16.78-23.50 \mathrm{mg} \mathrm{kg}^{-1}, 5.05-6.48 \mathrm{mg} \mathrm{g}^{-1}, 26.12-44.54$ and 25.44-35.94 under low $\mathrm{N}$ conditions, respectively. The ranges of $\mathrm{Fe}, \mathrm{Zn}$ and $\mathrm{Pa}$, and the molar ratios of $\mathrm{Fe}$ and $\mathrm{Zn}$ to Pa in open-pollinated seeds were $14.34-19.12 \mathrm{mg} \mathrm{kg}^{-1}, 17.27-23.27 \mathrm{mg} \mathrm{kg}^{-1}, 4.96-5.89 \mathrm{mg} \mathrm{g}^{-1}$, 20.90-28.22 and 22.92-29.37 under high $\mathrm{N}$, and 12.54-18.39 $\mathrm{mg} \mathrm{kg}^{-1}, 16.94-20.93 \mathrm{mg} \mathrm{kg}^{-1}, 5.30-6.17 \mathrm{mg} \mathrm{g}^{-1}$, 27.90-38.75 and 27.95-36.34 under low N conditions, respectively. The bioavailability of Fe and Zn was high in self-pollinated seeds under high $\mathrm{N}$ conditions, while Fe was higher in self-pollinated seeds, and Zn was higher in open-pollinated seeds under low $\mathrm{N}$ conditions. Combined over seasons, there were no significant differences between the values of Fe and $\mathrm{Zn}$ in self- and open-pollinated seeds under both high $\mathrm{N}$ and low $\mathrm{N}$ conditions. This indicated that unknown males had no influence on Fe and $\mathrm{Zn}$ concentration in maize. Therefore, either self- or open-pollinated seeds can be used for Fe and Zn determination in maize crosses.
\end{abstract}

Keywords: maize; hybrids; self-pollinated; open-pollinated; bioavailability

\section{Introduction}

Maize originated from the domestication of teosinte (Zea mays subspecies parviglumis) in mid-altitude regions of South-Central Mexico [1]. It has a large amount of genetic variability and is adapted to tropical, subtropical and temperate agroecological conditions [2]. It is the third most important cereal crop worldwide [3] and a staple food of millions of people in Asia, Latin America and Africa. It is the main staple and cash crop for about 300 million smallholder farmers in sub-Saharan Africa (SSA) [4,5] and is grown in diverse regions of SSA under various climatic and ecological conditions due to its extensive adoption and adaptation [6].

In many parts of the world, micronutrient deficiency and poor dietary quality are more widespread problems than low energy intake [7]. Factors responsible for micronutrient deficiency include poverty, lack of access to a balanced diet and variety of foods (such as meat and fish), plant-based foods with a low bioavailability of minerals, unawareness of good nutritional practices and a high incidence of infectious diseases [8]. The problem 
is exacerbated by a lack of stable government policies, safe distribution schemes and satisfactory investment [9]. The populations in developing countries are at a risk of developing zinc $(\mathrm{Zn})$ and iron (Fe) deficiencies due to their reliance on cereals as a staple in the diet [10]. Fe and $\mathrm{Zn}$ are most important for human health, especially for children and pregnant women. Fe is the main part of haemoglobin in red blood cells and transports oxygen from lungs to tissues. It is involved in energy production, immunity and thyroid function, and is the main component of cytochromes and ferredoxins [11,12]. $\mathrm{Zn}$ is mostly present in bones and skeletal muscles. It is responsible for the efficient functioning of more than 300 enzymes and acts as a stabiliser and protects membrane structure and cell components [13]. Deficiencies of $\mathrm{Zn}$ and Fe are in the fifth and sixth position among the top 10 most important risk factors responsible for causing illnesses and diseases in developing countries [12]. Fe and $\mathrm{Zn}$ deficiencies cause severe health problems such as impaired immune response and physical growth, impaired cognitive development, anaemia and morbidity in women and children under 5 years [14]. Fe and Zn deficiency affects more than 2 million people in the world, especially in low-income countries [15]. In cereals such as maize, $80 \%$ of the grain phosphorous is in the form of phytic acid and can be used as an indicator of the bioavailability of Fe and Zn [16]. The bioavailability of Fe decreases when the molar ratio of phytate/Fe is more than 1 , and the bioavailability of $\mathrm{Zn}$ decreases when the molar ratio of phytate $/ \mathrm{Zn}$ is more than 6 [17].

Nitrogen $(\mathrm{N})$ is a crucial nutrient needed for normal plant growth and development. It is the main component of chlorophyll, the photosynthetic pigment present in the leaves, which helps in the photosynthesis process [18]. Low levels of $\mathrm{N}$ in tropical soils constitute a major constraint to high crop productivity. Several decades of farming without the application of adequate fertiliser has resulted in depletion of the essential soil nutrients required to support plant growth [18-20]. Maize grain yield losses reach up to $10-50 \%$ annually due to low soil $\mathrm{N}$ in SSA $[19,20]$. Soil $\mathrm{N}$ stress prior to anthesis and silking decreases leaf area development, the photosynthesis rate and the number of ear rows, while nutrient stress during the anthesis and silking periods cause kernel and ear abortion, and, during grain-filling, enhances leaf senescence and lessens crop photosynthesis and kernel weight [21]. Biofortification of maize for Fe and $\mathrm{Zn}$ concentration can be done through breeding, but then enough genetic variation of these minerals in the seeds is necessary. Due to the large intake of maize in the human diet, biofortification for elements such as Fe and $\mathrm{Zn}$ is becoming crucial. Biofortification is a sustainable option to increase the nutritional value of maize for all consumers [22,23].

Xenia is the immediate effect of pollen on seed development after pollination. Earlier researchers observed that xenia's effects on Fe and $\mathrm{Zn}$ concentration in self- and openpollinated maize seeds [24,25]. Xenia also had an influence (immediate effect of pollen source) on seed size and nitrogen $(\mathrm{N})$ content in pearl millet and suggested that selfed seeds should be used for correct determination of the mineral content in cross-pollinated crops such as pearl millet and maize [26]. Selfing is the most cost-effective method for seed production; however, it is time-consuming and affects seed setting, depending on the genotype and environment [27]. Genotype by environment $(G \times E)$ interactions also affect grain $\mathrm{Fe}$ and $\mathrm{Zn}$ concentrations in maize. A significant $\mathrm{G} \times \mathrm{E}$ interaction for both grain $\mathrm{Fe}$ and $\mathrm{Zn}$ content was observed in a multiple-location trial with 20 early and 49 late maturing maize cultivars $[28,29]$. Since the effect of xenia on the concentration of Fe and $\mathrm{Zn}$ in maize grain has not been determined yet, this study aimed to compare open- and self-pollinated seed from the same hybrids, derived from crosses of parents varying in Fe and Zn content.

\section{Materials and Methods}

\subsection{Germplasm and Locations}

The plant material consisted of 9 parents, including 6 females and 3 males (Table 1) selected after screening 215 South African maize inbred lines obtained from the Agricultural Research Council (ARC)-Grain Cops Institute (ARC-GCI) for their concentration (low, medium and high) of Fe and Zn. The parents were planted in July 2016 at Makhathini 
Research Station and crossed following a line by tester $(6 \times 3)$ scheme, and $18 \mathrm{~F}_{1}$ maize hybrids (Table 2) were generated. The hybrids, along with the 9 parents, were planted in December 2016 and 2017 at Potchefstroom, Cedara and Vaalharts in South Africa, following a randomised complete block design with 2 replicates under high $\mathrm{N}$ and poor $\mathrm{N}$ conditions.

Table 1. List of parental material selected from 215 maize germplasm lines.

\begin{tabular}{ccccc}
\hline Parents & Pedigree & Fe (mg kg-1) & Zn $\left.\mathbf{~ ( m g ~ k g ~}^{-\mathbf{1}}\right)$ & Concentration \\
\hline Line-1 $\left(\mathrm{F}_{1}\right)$ & CBY075 LM-1574 & 340.0 & 105.0 & High \\
Line-2 $\left(\mathrm{F}_{2}\right)$ & CBY101 LM-1600 & 287.0 & 103.0 & High \\
Line-3 $\left(\mathrm{F}_{3}\right)$ & CBY102 LM-1601 & 116.5 & 49.5 & Medium \\
Line-4 $\left(\mathrm{F}_{4}\right)$ & CBY359 LM-1858 & 101.0 & 47.5 & Medium \\
Line-5 $\left(\mathrm{F}_{5}\right)$ & CBY017 LM-1516 & 55.5 & 18.0 & Low \\
Line-6 $\left(\mathrm{F}_{6}\right)$ & CBY014 LM-1513 & 45.0 & 10.5 & Low \\
Tester-1 $\left(\mathrm{M}_{1}\right)$ & CBY358 LM-1857 & 139.5 & 56.0 & High \\
Tester-2 $\left(\mathrm{M}_{2}\right)$ & CBY104 LM-1603 & 121.5 & 35.0 & Medium \\
Tester-3 $\left(\mathrm{M}_{3}\right)$ & CBY013 LM-1512 & 44.5 & 9.0 & Low \\
\hline
\end{tabular}

$\mathrm{F}=$ Female, $\mathrm{M}=$ Male.

Table 2. List of 18 hybrids generated from the line $\times$ tester crosses.

\begin{tabular}{ccc}
\hline Hybrids & Codes & Pedigree \\
\hline Line-1 $\times$ Tester-1 & SMH1 & CBY075 LM-1574 $\times$ CBY358 LM-1857 \\
Line-1 $\times$ Tester-2 & SMH7 & CBY075 LM-1574 $\times$ CBY104 LM-1603 \\
Line-1 $\times$ Tester-3 & SMH13 & CBY075 LM-1574 $\times$ CBY013 LM-1512 \\
Line-2 $\times$ Tester-1 & SMH2 & CBY075 LM-1574 $\times$ CBY358 LM-1857 \\
Line-2 $\times$ Tester-2 & SMH8 & CBY075 LM-1574 $\times$ CBY104 LM-1603 \\
Line-2 $\times$ Tester-3 & SMH14 & CBY075 LM-1574 $\times$ CBY013 LM-1512 \\
Line-3 $\times$ Tester-1 & SMH3 & CBY075 LM-1574 $\times$ CBY358 LM-1857 \\
Line-3 $\times$ Tester-2 & SMH9 & CBY075 LM-1574 $\times$ CBY104 LM-1603 \\
Line-3 $\times$ Tester-3 & SMH15 & CBY075 LM-1574 $\times$ CBY013 LM-1512 \\
Line-4 $\times$ Tester-1 & SMH4 & CBY075 LM-1574 $\times$ CBY358 LM-1857 \\
Line-4 $\times$ Tester-2 & SMH10 & CBY075 LM-1574 $\times$ CBY104 LM-1603 \\
Line-4 $\times$ Tester-3 & SMH16 & CBY075 LM-1574 $\times$ CBY013 LM-1512 \\
Line-5 $\times$ Tester-1 & SMH5 & CBY075 LM-1574 $\times$ CBY358 LM-1857 \\
Line-5 $\times$ Tester-2 & SMH11 & CBY075 LM-1574 $\times$ CBY104 LM-1603 \\
Line-5 $\times$ Tester-3 & SMH17 & CBY075 LM-1574 $\times$ CBY013 LM-1512 \\
Line-6 $\times$ Tester-1 & SMH6 & CBY075 LM-1574 $\times$ CBY358 LM-1857 \\
Line-6 $\times$ Tester-2 & SMH12 & CBY075 LM-1574 $\times$ CBY104 LM-1603 \\
Line-6 $\times$ Tester-3 & SMH18 & CBY075 LM-1574 $\times$ CBY013 LM-1512 \\
\hline
\end{tabular}

$\overline{\mathrm{SMH}}=$ Sajjad maize hybrid.

Potchefstroom is in the Tlokwe municipality of the Northwest (NW) province, and lies at $-26.73^{\circ}$ latitude and $27.08^{\circ}$ longitude at an altitude of $1349 \mathrm{~m}$ above sea level $(\mathrm{m}$ asl), with brown sandy loam soils. Low $\mathrm{N}$ conditions were created by depleting the soil of $\mathrm{N}$, by planting maize for several years without $\mathrm{N}$ fertilisation and removing all stover from the field. Under managed conditions, the soil was considered low $\mathrm{N}$ when it had approximately $7 \mathrm{ppm}$ $\mathrm{N}$ (translating to $54 \mathrm{~kg} \mathrm{ha}^{-1}$ ) in the upper $60 \mathrm{~cm}$ soil depth, allowing the soil to still supply some $\mathrm{N}$ to plants [30]. The fertiliser regime for high $\mathrm{N}$ conditions was a compound fertiliser (3:2:1 $+\mathrm{Zn}$ ) applied as a basal application at planting at a rate of $200 \mathrm{~kg} \mathrm{NPK} \mathrm{ha}^{-1}$ to optimum $\mathrm{N}$ plots. Calcium ammonium nitrate (CAN) with $28 \% \mathrm{~N}$ was used for topdressing in 2 equal splits at 28 and 56 days after emergence at a rate of $100 \mathrm{~kg} \mathrm{ha}^{-1}$ each in optimum N plots only. In low N plots, NPK was applied at the rate of $100 \mathrm{~kg} \mathrm{ha}^{-1}$.

Cedara is in the uMngeni municipality of the KwaZulu-Natal (KZN) province, and lies at $-29.54^{\circ}$ latitude and $30.26^{\circ}$ longitude at an altitude of $1066 \mathrm{~m}$ asl, with reddish-brown clay soils. The fertiliser used was mono-ammonium phosphate (MAP) at $250 \mathrm{~kg} \mathrm{ha}^{-1}$ at planting for the optimum $\mathrm{N}$ environments or at $30 \mathrm{~kg} \mathrm{ha}^{-1}$ in the low $\mathrm{N}$ environment, and CAN was given at $150 \mathrm{~kg} \mathrm{ha}^{-1}$ in 2 equal splits of $75 \mathrm{~kg} \mathrm{ha}^{-1}$ for the optimum N plots 
only at 28 and 56 days after emergence. The Vaalharts is in the Northern Cape Province at $28^{\circ} 06^{\prime} 56.84^{\prime \prime} \mathrm{S} 24^{\circ} 55^{\prime} 32.50^{\prime \prime} \mathrm{E}$ at an altitude of $1192 \mathrm{~m}$ asl. Fertiliser was applied at the same rate as in Potchefstroom. All standard agronomic practices were applied in the trials. The total amounts of mineral $\mathrm{N}$ (basal + topdressing) applied in the 3 locations under optimum and poor conditions. Trials were grown under dryland conditions, which is the norm for the trial areas. The distances between plants and rows were $0.25 \mathrm{~m}$ and $0.75 \mathrm{~m}$, respectively at all locations. In each plot, there were two rows $4 \mathrm{~m}$ in length. The plot size was $6 \mathrm{~m}^{2}$. Five healthy plants from the middle of each plot were selected for data collection. Soil analysis data are presented in Table 3.

Table 3. Soil analysis of the experimental sites used.

\begin{tabular}{|c|c|c|c|c|c|c|c|}
\hline \multirow{3}{*}{ Minerals } & \multirow{3}{*}{$\begin{array}{c}\text { Soil } \\
\text { Depth (cm) }\end{array}$} & \multicolumn{2}{|c|}{ Potchefstroom } & \multicolumn{2}{|c|}{ Cedara } & \multicolumn{2}{|c|}{ Vaalharts } \\
\hline & & High N & Low N & High N & Low N & High N & Low N \\
\hline & & 2016-17 & 2016-17 & 2016-17 & 2016-17 & 2016-17 & 2016-17 \\
\hline \multirow{2}{*}{$\mathrm{Fe}\left(\mathrm{mg} \mathrm{kg}{ }^{-1}\right)$} & $0-30$ & 11.9 & 10.0 & 13.5 & 9.6 & 7.0 & 5.9 \\
\hline & $30-60$ & 10.6 & 8.4 & 11.9 & 10.1 & 6.6 & 5.9 \\
\hline \multirow{2}{*}{$\mathrm{Zn}\left(\mathrm{mg} \mathrm{kg}^{-1}\right)$} & $0-30$ & 9.4 & 9.0 & 1.3 & 3.2 & 3.3 & 2.5 \\
\hline & $30-60$ & 8.6 & 5.6 & 1.4 & 2.2 & 2.9 & 2.3 \\
\hline \multirow{2}{*}{$\mathrm{P}\left(\mathrm{mg} \mathrm{kg}{ }^{-1}\right)$} & $0-30$ & 27.9 & 15.5 & 11.7 & 12.8 & 52.3 & 32.4 \\
\hline & $30-60$ & 35.7 & 12.6 & 10.5 & 10.1 & 44.7 & 29.3 \\
\hline \multirow{2}{*}{$\mathrm{K}\left(\mathrm{mg} \mathrm{kg}^{-1}\right)$} & $0-30$ & 278.5 & 198.4 & 77.0 & 174.5 & 123 & 163 \\
\hline & $30-60$ & 314.9 & 209.7 & 70.5 & 120.0 & 114 & 149 \\
\hline \multirow{2}{*}{$\mathrm{Ca}\left(\mathrm{mg} \mathrm{kg}^{-1}\right)$} & $0-30$ & 830.0 & 666.0 & 513.0 & 699.0 & 436 & 535 \\
\hline & $30-60$ & 952.0 & 887.0 & 511.0 & 694.0 & 402 & 500 \\
\hline \multirow{2}{*}{$\operatorname{Mg}\left(\mathrm{mg} \mathrm{kg}^{-1}\right)$} & $0-30$ & 384.9 & 328.5 & 99.0 & 166.0 & 141 & 174 \\
\hline & $30-60$ & 440.7 & 438.9 & 99.5 & 154.0 & 128 & 169 \\
\hline \multirow{2}{*}{$\mathrm{Mn}\left(\mathrm{mg} \mathrm{kg}^{-1}\right)$} & $0-30$ & 38.9 & 35.1 & 3.6 & 3.4 & 11.1 & 13.2 \\
\hline & $30-60$ & 43.8 & 26.9 & 3.6 & 2.3 & 9.2 & 13.1 \\
\hline \multirow{2}{*}{ Soil pH } & $0-30$ & 6.5 & 6.1 & 4.3 & 4.4 & 6.0 & 6.3 \\
\hline & $30-60$ & 6.6 & 6.0 & 4.4 & 4.5 & 6.1 & 6.3 \\
\hline
\end{tabular}

\subsection{Self- and Open-Pollinated Seeds}

The selected cobs of 5 healthy hybrid plants of uniform height from each plot were closed for self-pollination. The cobs of the rest of the plants in each plot were left open for cross-pollination with unknown males. On selected plants, the silk was covered with a small polythene bag after emergence to avoid contamination, and the tassel was covered with a brown paper bag for pollen collection. The next morning, pollen was collected in the brown paper bag and the silk was self-pollinated and covered again with the same brown paper bag. At maturity, the self- and open-pollinated ears (with $12.5 \%$ moisture) were harvested and shelled manually. Shelled seeds were dried in the shade and then weighed and ground for Fe and $\mathrm{Zn}$ analysis.

\subsection{Biochemical Analysis}

The analysis was performed according to the dry-ashing method outlined by the AOAC [31] in the Soil Science Laboratory, University of the Free State, Bloemfontein, South Africa. Phytic acid analysis was performed following the method of Dragičević et al. [32] with some modifications. A standard curve for phytic acid determination was prepared in MS Excel and calculations were carried out according to Latta and Eskin [33]. Moles of Fe, $\mathrm{Zn}$ and $\mathrm{Pa}$ were calculated by dividing the weight of $\mathrm{Pa}, \mathrm{Fe}$ and $\mathrm{Zn}$ by their atomic masses and then the molar ratios of Fe and $\mathrm{Zn}$ were calculated by dividing the moles of Pa by the moles of the minerals [34]. 


\subsection{Grain Yield}

Grain yield (GY) was measured as $\mathrm{kg}^{\mathrm{plot}}{ }^{-1}$ using an electronic balance and then GY was converted to tons per hectare $\left(\mathrm{t} \mathrm{ha}^{-1}\right)$ at $12.5 \%$ moisture by using the following Equation [35]:

Grain yield $\left(\mathrm{t} \mathrm{ha}^{-1}\right)=($ Shelled grain weight $/ 1000) \times($ Adjusted grain moisture at 12.5$) \times($ Area factor $)$

where shelled grain weight $(\mathrm{kg}) / 1000$ is the weight converted into tons and the adjusted standard factor of grain moisture at $12.5 \%$ was the 100 -grain moisture measured at harvest $(\%) /(100-12.5)$.

Grain moisture was measured using a moisture meter for maize in the field at harvesting time.

\subsection{Statistical Analysis}

Analyses of variance for single and combined locations were performed using Agrobase software [36]. Please note that due to the unavailability of self-data at 1 location in the first year and of the second location in the second year, the data of 2 locations were used for the final analysis of variance (ANOVA) and the degrees of freedom of location is 1 instead of 2 .

\section{Results}

\subsection{Season 1 (2016-2017)}

High $\mathrm{N}$ conditions: The ranges of Fe, $\mathrm{Zn}, \mathrm{Pa}, \mathrm{Fe}: \mathrm{Pa}$ and $\mathrm{Zn}: \mathrm{Pa}$ in self-pollinated maize seeds were $15.11-21.49 \mathrm{mg} \mathrm{kg}^{-1}, 18.20-25.38 \mathrm{mg} \mathrm{kg}^{-1}, 4.18-5.83 \mathrm{mg} \mathrm{g}^{-1}, 19.64-28.73$ and 17.82-27.64, respectively. The ranges of $\mathrm{Fe}, \mathrm{Zn}, \mathrm{Pa}, \mathrm{Fe}: \mathrm{Pa}$ and $\mathrm{Zn}: \mathrm{Pa}$ in open-pollinated maize seeds were $12.18-18.19 \mathrm{mg} \mathrm{kg}^{-1}, 16.22-21.73 \mathrm{mg} \mathrm{kg}^{-1}, 4.35-5.68 \mathrm{mg} \mathrm{g}^{-1}, 19.99-26.72$ and 21.14-28.95, respectively (Table S1).

The hybrid, location and hybrid $\times$ location effects were highly significant for all characteristics (except for Fe and $\mathrm{Zn}$ to Pa molar ratios in the case of location) in both types of seed (Table S2).

Low N conditions: The ranges of Fe, Zn, Pa, Fe:Pa and Zn:Pa in self-pollinated maize seeds were $12.88-22.11 \mathrm{mg} \mathrm{kg}^{-1}, 14.98-21.34 \mathrm{mg} \mathrm{kg}^{-1}, 4.86-6.63 \mathrm{mg} \mathrm{g}^{-1}, 23.46-38.62$ and 27.99-40.35, respectively. The ranges of Fe, Zn, Pa, Fe:Pa and Zn:Pa in open-pollinated maize seeds were $11.58-20.77 \mathrm{mg} \mathrm{kg}^{-1}, 12.51-18.86 \mathrm{mg} \mathrm{kg}^{-1}, 4.47-6.01 \mathrm{mg} \mathrm{g}^{-1}, 24.67-39.23$ and 28.63-45.54, respectively (Table S3).

The hybrid effect was highly significant for $\mathrm{Fe}, \mathrm{Zn}, \mathrm{Pa}, \mathrm{Fe}: \mathrm{Pa}$ and $\mathrm{Zn}$ : $\mathrm{Pa}$ in both types of seed. The location effect was highly significant in self- (significant for Pa) and open-pollinated (except for $\mathrm{Zn}$ ) maize seeds for the measured characteristics. The hybrid $\times$ location effect was highly significant for Fe, $\mathrm{Zn}, \mathrm{Fe}: \mathrm{Pa}$ and $\mathrm{Zn}: \mathrm{Pa}$, and significant for $\mathrm{Pa}$ in both types of maize seed (Table S4).

\subsection{Season 2 (2017-2018)}

High N conditions: The ranges of Fe, Zn, Pa, Fe:Pa and Zn:Pa in self-pollinated maize seeds were 12.64-21.93 $\mathrm{mg} \mathrm{kg}^{-1}, 17.95-23.30 \mathrm{mg} \mathrm{kg}^{-1}, 4.98-6.30 \mathrm{mg} \mathrm{g}^{-1}, 21.07-41.40$ and 25.62-34.71, respectively. The ranges of $\mathrm{Fe}, \mathrm{Zn}, \mathrm{Pa}, \mathrm{Fe}: \mathrm{Pa}$ and $\mathrm{Zn}: \mathrm{Pa}$ in open-pollinated maize seeds were $15.77-21.94 \mathrm{mg} \mathrm{kg}^{-1}, 18.33-24.80 \mathrm{mg} \mathrm{kg}^{-1}, 5.18-6.29 \mathrm{mg} \mathrm{g}^{-1}, 20.33-31.74$ and 23.45-31.50, respectively (Table S5). The hybrid, location and hybrid $\times$ location effects were highly significant for all characteristics in both types of maize seed (Table S6).

Low $\mathrm{N}$ conditions: The ranges of Fe, $\mathrm{Zn}, \mathrm{Pa}, \mathrm{Fe}: \mathrm{Pa}$ and $\mathrm{Zn}: \mathrm{Pa}$ in self-pollinated maize seeds were $10.87-17.76 \mathrm{mg} \mathrm{kg}^{-1}, 15.90-27.58 \mathrm{mg} \mathrm{kg}^{-1}, 5.19-6.89 \mathrm{mg} \mathrm{g}^{-1}, 26.83-55.64$ and 22.49-36.85, respectively. The ranges of Fe, $\mathrm{Zn}, \mathrm{Pa}$, Fe:Pa and $\mathrm{Zn}: \mathrm{Pa}$ in open-pollinated maize seeds were 12.46-18.64 $\mathrm{mg} \mathrm{kg}^{-1}, 17.90-23.56 \mathrm{mg} \mathrm{kg}^{-1}, 5.65-6.99 \mathrm{mg} \mathrm{g}^{-1}, 30.08-48.82$ and 26.56-35.39, respectively (Table S7). The hybrid, location and hybrid $\times$ location effects were highly significant for Fe, Zn, Pa, Fe:Pa and Zn: Pa in both types of maize seed (Table S8). 


\subsection{Both Seasons Combined}

High $\mathrm{N}$ conditions: The ranges of $\mathrm{Fe}, \mathrm{Zn}$ and $\mathrm{Pa}$, and the molar ratios of $\mathrm{Fe}$ and $\mathrm{Zn}$ to $\mathrm{Pa}$ in self-pollinated maize seeds were $15.93-21.36 \mathrm{mg} \mathrm{kg}^{-1}, 18.50-24.34 \mathrm{mg} \mathrm{kg}^{-1}, 4.63-5.84 \mathrm{mg} \mathrm{g}^{-1}$, 21.97-31.22 and 23.53-30.16, respectively. The ranges of $\mathrm{Fe}, \mathrm{Zn}$ and $\mathrm{Pa}$, and the molar ratios of Fe and $\mathrm{Zn}$ to Pa in open-pollinated seeds were $14.34-19.12 \mathrm{mg} \mathrm{kg}^{-1}, 17.27-23.27 \mathrm{mg} \mathrm{kg}^{-1}$, 4.96-5.89 $\mathrm{mg} \mathrm{g}^{-1}, 20.90-28.22$ and 22.92-29.37, respectively (Table 4). The effects of location, entry, season (non-significant for Fe), location $\times$ entry, location $\times$ season, entry $\times$ season (non-significant for $\mathrm{Zn}: \mathrm{Pa}$ ) and location $\times$ entry $\times$ season were highly significant for all characteristics in self- as well as in open-pollinated maize seeds under high $\mathrm{N}$ conditions (Table 5).

Table 4. Mean performance for $\mathrm{Fe}, \mathrm{Zn}$ and $\mathrm{Pa}$, and the molar ratios of Fe and $\mathrm{Zn}$ to Pa in self- and open-pollinated maize seeds under high $\mathrm{N}$ conditions during both seasons.

\begin{tabular}{|c|c|c|c|c|c|c|}
\hline Hybrids & Pollination & $\mathrm{Fe}\left(\mathrm{mg} \mathrm{kg}^{-1}\right)$ & $\mathrm{Zn}\left(\mathrm{mg} \mathrm{kg}{ }^{-1}\right)$ & $\mathrm{Pa}\left(\mathrm{mg} \mathrm{g}^{-1}\right)$ & Fe:Pa & $\mathrm{Zn}: \mathrm{Pa}$ \\
\hline \multirow{2}{*}{ SMH1 } & Self & 21.36 & 22.53 & 5.68 & 22.70 & 24.89 \\
\hline & Open & 16.84 & 21.22 & 5.89 & 25.56 & 26.75 \\
\hline \multirow{2}{*}{ SMH2 } & Self & 16.91 & 21.93 & 5.10 & 26.63 & 23.85 \\
\hline & Open & 17.29 & 20.85 & 5.11 & 21.71 & 23.57 \\
\hline \multirow[b]{2}{*}{ SMH3 } & Self & 15.93 & 22.99 & 5.28 & 31.22 & 23.66 \\
\hline & Open & 19.12 & 21.18 & 5.53 & 23.85 & 25.11 \\
\hline \multirow{2}{*}{ SMH4 } & Self & 20.14 & 24.34 & 5.56 & 24.34 & 23.72 \\
\hline & Open & 17.67 & 23.27 & 5.53 & 21.94 & 22.92 \\
\hline \multirow{2}{*}{ SMH5 } & Self & 19.80 & 19.66 & 5.24 & 22.65 & 27.05 \\
\hline & Open & 17.61 & 21.06 & 5.14 & 22.07 & 23.34 \\
\hline \multirow[b]{2}{*}{ SMH6 } & Self & 18.60 & 19.63 & 5.11 & 24.77 & 27.11 \\
\hline & Open & 15.50 & 20.00 & 5.35 & 26.31 & 25.50 \\
\hline \multirow{2}{*}{ SMH7 } & Self & 17.10 & 19.23 & 5.84 & 29.79 & 30.08 \\
\hline & Open & 15.65 & 17.92 & 5.42 & 27.04 & 28.54 \\
\hline \multirow{2}{*}{ SMH8 } & Self & 19.11 & 19.31 & 5.39 & 24.16 & 29.29 \\
\hline & Open & 15.89 & 17.27 & 5.00 & 25.52 & 27.69 \\
\hline \multirow{2}{*}{ SMH9 } & Self & 18.66 & 19.05 & 5.42 & 24.45 & 27.93 \\
\hline & Open & 16.24 & 19.50 & 5.52 & 24.28 & 26.84 \\
\hline \multirow{2}{*}{ SMH10 } & Self & 17.60 & 20.02 & 5.20 & 25.81 & 27.56 \\
\hline & Open & 17.26 & 19.19 & 5.32 & 24.14 & 26.54 \\
\hline \multirow{2}{*}{ SMH11 } & Self & 19.25 & 18.50 & 5.26 & 24.41 & 28.87 \\
\hline & Open & 18.12 & 18.36 & 5.15 & 22.20 & 26.92 \\
\hline \multirow[b]{2}{*}{ SMH12 } & Self & 18.12 & 20.33 & 4.63 & 21.99 & 23.76 \\
\hline & Open & 18.23 & 18.88 & 5.31 & 23.23 & 26.98 \\
\hline \multirow[b]{2}{*}{ SMH13 } & Self & 17.57 & 20.08 & 5.81 & 29.07 & 29.31 \\
\hline & Open & 15.25 & 20.01 & 5.87 & 28.22 & 28.17 \\
\hline \multirow{2}{*}{ SMH14 } & Self & 16.53 & 20.01 & 4.83 & 25.75 & 23.53 \\
\hline & Open & 14.34 & 17.99 & 4.96 & 25.23 & 26.26 \\
\hline \multirow{2}{*}{ SMH15 } & Self & 16.97 & 19.12 & 5.75 & 29.23 & 30.16 \\
\hline & Open & 16.70 & 17.99 & 5.49 & 27.58 & 29.37 \\
\hline \multirow{2}{*}{ SMH16 } & Self & 16.33 & 19.55 & 5.54 & 28.96 & 28.66 \\
\hline & Open & 15.66 & 19.92 & 5.70 & 25.95 & 27.79 \\
\hline \multirow{2}{*}{ SMH17 } & Self & 20.44 & 19.82 & 5.12 & 23.20 & 26.89 \\
\hline & Open & 16.33 & 18.43 & 5.26 & 24.39 & 27.57 \\
\hline \multirow{2}{*}{ SMH18 } & Self & 19.72 & 19.62 & 5.10 & 21.97 & 25.84 \\
\hline & Open & 19.08 & 20.08 & 5.15 & 20.90 & 24.72 \\
\hline \multirow[b]{2}{*}{ Mean } & Self & 18.34 & 20.32 & 5.33 & 25.62 & 26.79 \\
\hline & Open & 16.82 & 19.62 & 5.37 & 24.45 & 26.37 \\
\hline \multirow{2}{*}{$\mathrm{LSD}_{0.05}$} & Self & 0.60 & 0.73 & 0.37 & 2.44 & 2.25 \\
\hline & Open & 0.65 & 0.88 & 0.17 & 1.47 & 1.38 \\
\hline
\end{tabular}

$\mathrm{SMH}=$ Sajjad maize hybrid; Fe = iron; $\mathrm{Zn}=$ zinc; $\mathrm{Pa}=$ phytic acid; Fe:Pa = molar ratio of Fe to $\mathrm{Pa} ; \mathrm{Zn}: \mathrm{Pa}=$ molar ratio of $\mathrm{Zn}$ to Pa; LSD = least significant difference. 
Table 5. Analysis of variance showing mean squares for $\mathrm{Fe}, \mathrm{Zn}$ and $\mathrm{Pa}$, and the molar ratios of Fe and $\mathrm{Zn}$ to $\mathrm{Pa}$ in self and open-pollinated maize seeds under high $\mathrm{N}$ conditions during both seasons.

\begin{tabular}{|c|c|c|c|c|c|c|c|}
\hline Source & df & Pollination & $\mathrm{Fe}\left(\mathrm{mg} \mathrm{kg}^{-1}\right)$ & $\mathrm{Zn}\left(\mathrm{mg} \mathrm{kg}^{-1}\right)$ & $\mathrm{Pa}\left(\mathrm{mg} \mathrm{g}^{-1}\right)$ & Fe:Pa & $\mathrm{Zn}: \mathbf{P a}$ \\
\hline \multirow{2}{*}{$\begin{array}{l}\text { Block in } \\
(\mathrm{L} \times \mathrm{Y})\end{array}$} & \multirow{2}{*}{4} & Self & 1.00 & 0.59 & 1.01 & 36.51 & 27.76 \\
\hline & & Open & 0.96 & 1.16 & 0.12 & 3.37 & 5.46 \\
\hline \multirow{2}{*}{$\begin{array}{l}\text { Location } \\
\text { (L) }\end{array}$} & \multirow{2}{*}{1} & Self & $6.27^{* * *}$ & $259.13^{* * *}$ & $10.82 * * *$ & $104.24^{* * *}$ & $1743.20^{* * *}$ \\
\hline & & Open & $56.32 * * *$ & $114.92^{* * *}$ & $11.81^{* * *}$ & $125.28^{* * *}$ & $724.93^{* * *}$ \\
\hline \multirow{2}{*}{ Entry (E) } & \multirow{2}{*}{17} & Self & $19.85^{* * *}$ & $19.67^{* * *}$ & $0.88^{* * *}$ & $67.27^{* * *}$ & $45.55^{* * *}$ \\
\hline & & Open & $21.42^{* * *}$ & $20.20 * * *$ & $0.89 * * *$ & $55.45^{* * *}$ & $40.40^{* * *}$ \\
\hline \multirow{2}{*}{ Year (Y) } & \multirow{2}{*}{1} & Self & 0.01 & $22.35^{* * *}$ & $48.28^{* * *}$ & $1351.05^{* * *}$ & $2214.33^{* * *}$ \\
\hline & & Open & $1158.42 * * *$ & $108.08^{* * *}$ & $24.58^{* * *}$ & $538.72 * * *$ & $599.33^{* * *}$ \\
\hline \multirow{2}{*}{$\mathrm{L} \times \mathrm{E}$} & \multirow[b]{2}{*}{17} & Self & $23.25^{* * *}$ & $7.67^{* * *}$ & $0.45^{* *}$ & $55.23^{* * *}$ & $28.86^{* * *}$ \\
\hline & & Open & $17.77^{* * *}$ & $12.21^{* * *}$ & $0.52^{* * *}$ & $27.75^{* * *}$ & $22.59 * * *$ \\
\hline \multirow{2}{*}{$\mathrm{L} \times \mathrm{Y}$} & \multirow[b]{2}{*}{1} & Self & $350.19 * * *$ & $384.98^{* * *}$ & $13.40^{* * *}$ & $1631.62 * * *$ & $2257.99 * * *$ \\
\hline & & Open & $22.24^{* * *}$ & $63.96^{* * *}$ & $6.34 * * *$ & $168.81^{* * *}$ & $515.03^{* * *}$ \\
\hline \multirow[b]{2}{*}{$E \times Y$} & \multirow[b]{2}{*}{17} & Self & $13.41^{* * *}$ & $3.22 * * *$ & $0.53^{* *}$ & $37.21^{* * *}$ & 10.37 \\
\hline & & Open & $12.23^{* * *}$ & $6.73^{* * *}$ & $0.29^{* * *}$ & $34.25^{* * *}$ & $15.46^{* * *}$ \\
\hline \multirow{2}{*}{$\underset{\mathrm{Y}}{\mathrm{L} \times \mathrm{E} \times}$} & \multirow{2}{*}{17} & Self & $18.00^{* * *}$ & $16.28^{* * *}$ & $0.51 * *$ & $61.63^{* * *}$ & $46.30^{* * *}$ \\
\hline & & Open & $15.72^{* * *}$ & $5.89 * * *$ & $0.56^{* * *}$ & $31.03^{* * *}$ & $20.42^{* * *}$ \\
\hline \multirow{2}{*}{ Residual } & \multirow[b]{2}{*}{68} & Self & 0.51 & 0.77 & 0.20 & 8.58 & 7.28 \\
\hline & & Open & 0.91 & 1.69 & 0.06 & 4.68 & 4.17 \\
\hline \multirow{2}{*}{$\mathrm{R}^{2}$ value } & & Self & 0.98 & 0.97 & 0.90 & 0.92 & 0.94 \\
\hline & & Open & 0.97 & 0.91 & 0.95 & 0.91 & 0.93 \\
\hline
\end{tabular}

${ }^{* *} p \leq 0.01 ;{ }^{* * *} p \leq 0.001 ; \mathrm{df}=$ degrees of freedom; $\mathrm{Fe}=$ iron; $\mathrm{Zn}=$ zinc; $\mathrm{Pa}=$ phytic acid; Fe:Pa = molar ratio of Fe to Pa; $\mathrm{Zn}: \mathrm{Pa}=$ molar ratio of $\mathrm{Zn}$ to $\mathrm{Pa}$.

Low $\mathrm{N}$ conditions: The ranges of $\mathrm{Fe}, \mathrm{Zn}$ and $\mathrm{Pa}$, and the molar ratios of $\mathrm{Fe}$ and $\mathrm{Zn}$ to $\mathrm{Pa}$ in self-pollinated maize seeds were $12.76-19.29 \mathrm{mg} \mathrm{kg}^{-1}, 16.78-23.50 \mathrm{mg} \mathrm{kg}^{-1}$, $5.05-6.48 \mathrm{mg} \mathrm{g}^{-1}, 26.12-44.54$ and 25.44-35.94, respectively. The ranges of $\mathrm{Fe}, \mathrm{Zn}, \mathrm{Pa}$ and the molar ratios of $\mathrm{Fe}$ and $\mathrm{Zn}$ to $\mathrm{Pa}$ in open-pollinated seeds were $12.54-18.39 \mathrm{mg} \mathrm{kg}^{-1}$, 16.94-20.93 mg kg$-1,5.30-6.17 \mathrm{mg} \mathrm{g}^{-1}, 27.90-38.75$ and 27.95-36.34, respectively (Table 6). The effects of location, entry, season (significant for Pa), location $\times$ entry, location $\times$ season, entry $\times$ season (significant for Pa) and location $\times$ entry $\times$ season were highly significant for all characteristics in self- as well as in open-pollinated maize seeds under high $\mathrm{N}$ and low $\mathrm{N}$ conditions (Table 7).

Table 6. Mean performance for $\mathrm{Fe}, \mathrm{Zn}$ and $\mathrm{Pa}$, and the molar ratios of Fe and $\mathrm{Zn}$ to Pa in self- and open-pollinated maize seeds under low $\mathrm{N}$ conditions during both seasons.

\begin{tabular}{|c|c|c|c|c|c|c|}
\hline Hybrids & Pollination & $\mathrm{Fe}\left(\mathrm{mg} \mathrm{kg}^{-1}\right)$ & $\mathrm{Zn}\left(\mathrm{mg} \mathrm{kg}^{-1}\right)$ & $\mathrm{Pa}\left(\mathrm{mg} \mathrm{g}^{-1}\right)$ & Fe:Pa & $\mathrm{Zn}: \mathrm{Pa}$ \\
\hline \multirow{2}{*}{ SMH1 } & Self & 15.11 & 20.21 & 6.37 & 44.54 & 33.19 \\
\hline & Open & 18.39 & 19.20 & 5.81 & 27.90 & 31.98 \\
\hline \multirow{2}{*}{$\mathrm{SMH} 2$} & Self & 19.12 & 23.50 & 6.13 & 26.51 & 28.20 \\
\hline & Open & 15.96 & 20.93 & 6.13 & 33.89 & 30.74 \\
\hline \multirow{2}{*}{ SMH3 } & Self & 16.83 & 20.19 & 5.89 & 32.82 & 30.45 \\
\hline & Open & 13.59 & 19.81 & 6.00 & 37.52 & 30.96 \\
\hline \multirow{2}{*}{$\mathrm{SMH} 4$} & Self & 14.72 & 21.37 & 6.39 & 38.32 & 30.38 \\
\hline & Open & 17.80 & 19.70 & 6.08 & 31.67 & 32.61 \\
\hline \multirow[b]{2}{*}{ SMH5 } & Self & 15.80 & 20.71 & 6.48 & 39.51 & 32.41 \\
\hline & Open & 16.29 & 18.97 & 6.13 & 34.72 & 35.15 \\
\hline \multirow{2}{*}{ SMH6 } & Self & 15.85 & 18.41 & 5.62 & 28.88 & 29.55 \\
\hline & Open & 16.66 & 18.97 & 5.30 & 29.44 & 27.95 \\
\hline \multirow{2}{*}{ SMH7 } & Self & 19.29 & 17.49 & 6.29 & 27.46 & 33.40 \\
\hline & Open & 13.69 & 18.58 & 6.17 & 38.57 & 33.39 \\
\hline \multirow{2}{*}{ SMH8 } & Self & 13.28 & 18.30 & 5.95 & 38.76 & 33.42 \\
\hline & Open & 12.81 & 18.04 & 6.14 & 38.75 & 33.91 \\
\hline
\end{tabular}


Table 6. Cont.

\begin{tabular}{|c|c|c|c|c|c|c|}
\hline Hybrids & Pollination & $\mathrm{Fe}\left(\mathrm{mg} \mathrm{kg}^{-1}\right)$ & $\mathrm{Zn}\left(\mathrm{mg} \mathrm{kg}^{-1}\right)$ & $\mathrm{Pa}\left(\mathrm{mg} \mathrm{g}^{-1}\right)$ & $\mathrm{Fe}: \mathrm{Pa}$ & $\mathrm{Zn}: \mathrm{Pa}$ \\
\hline \multirow{2}{*}{ SMH9 } & Self & 13.56 & 17.37 & 5.70 & 35.03 & 34.37 \\
\hline & Open & 16.11 & 16.94 & 5.74 & 33.65 & 33.43 \\
\hline \multirow{2}{*}{ SMH10 } & Self & 17.63 & 21.01 & 6.21 & 31.79 & 29.64 \\
\hline & Open & 15.20 & 18.15 & 5.94 & 35.59 & 32.30 \\
\hline \multirow[b]{2}{*}{ SMH11 } & Self & 15.64 & 20.72 & 5.05 & 30.63 & 27.70 \\
\hline & Open & 17.18 & 18.15 & 5.81 & 31.36 & 31.78 \\
\hline \multirow{2}{*}{ SMH12 } & Self & 15.26 & 17.14 & 5.80 & 38.03 & 34.04 \\
\hline & Open & 15.12 & 17.67 & 5.48 & 31.15 & 31.28 \\
\hline \multirow{2}{*}{ SMH13 } & Self & 15.18 & 17.35 & 5.87 & 36.82 & 33.01 \\
\hline & Open & 15.88 & 18.47 & 6.13 & 33.74 & 33.39 \\
\hline \multirow{2}{*}{ SMH14 } & Self & 12.76 & 17.63 & 5.83 & 42.11 & 29.41 \\
\hline & Open & 12.54 & 17.04 & 5.47 & 34.76 & 31.91 \\
\hline \multirow{2}{*}{ SMH15 } & Self & 14.03 & 17.11 & 5.84 & 31.82 & 35.94 \\
\hline & Open & 14.40 & 18.13 & 6.07 & 38.53 & 34.09 \\
\hline \multirow{2}{*}{ SMH16 } & Self & 18.32 & 21.07 & 5.97 & 29.63 & 27.19 \\
\hline & Open & 15.38 & 17.82 & 6.16 & 33.86 & 36.34 \\
\hline \multirow[b]{2}{*}{ SMH17 } & Self & 16.81 & 19.42 & 5.14 & 26.12 & 25.44 \\
\hline & Open & 17.21 & 18.39 & 5.45 & 28.20 & 29.82 \\
\hline \multirow{2}{*}{ SMH18 } & Self & 14.83 & 16.78 & 5.27 & 32.32 & 30.56 \\
\hline & Open & 14.64 & 18.01 & 5.48 & 33.06 & 31.11 \\
\hline \multirow[b]{2}{*}{ Mean } & Self & 15.78 & 19.21 & 5.88 & 33.95 & 31.02 \\
\hline & Open & 15.49 & 18.50 & 5.88 & 33.69 & 32.34 \\
\hline \multirow{2}{*}{$\mathrm{LSD}_{0.05}$} & Self & 1.09 & 1.14 & 0.38 & 3.20 & 2.93 \\
\hline & Open & 0.57 & 1.05 & 0.33 & 2.55 & 2.82 \\
\hline
\end{tabular}

$\mathrm{SMH}=$ Sajjad maize hybrid; $\mathrm{Fe}=$ iron; $\mathrm{Zn}=$ zinc; $\mathrm{Pa}=$ phytic acid; Fe:Pa = molar ratio of Fe to $\mathrm{Pa} ; \mathrm{Zn}: \mathrm{Pa}=$ molar ratio of $\mathrm{Zn}$ to $\mathrm{Pa} ; \mathrm{LSD}=$ least significant difference.

Table 7. Analysis of variance showing the mean squares for $\mathrm{Fe}, \mathrm{Zn}$ and $\mathrm{Pa}$, and the molar ratios of $\mathrm{Fe}$ and $\mathrm{Zn}$ to $\mathrm{Pa}$ in selfand open-pollinated maize seeds under low $\mathrm{N}$ conditions during both seasons.

\begin{tabular}{|c|c|c|c|c|c|c|c|}
\hline Source & df & Pollination & $\mathrm{Fe}\left(\mathrm{mg} \mathrm{kg}{ }^{-1}\right)$ & $\mathrm{Zn}\left(\mathrm{mg} \mathrm{kg}^{-1}\right)$ & $\mathrm{Pa}\left(\mathrm{mg} \mathrm{g}^{-1}\right)$ & Fe:Pa & $\mathrm{Zn}: \mathrm{Pa}$ \\
\hline \multirow{2}{*}{$\begin{array}{l}\text { Block in } \\
(\mathrm{L} \times \mathrm{Y})\end{array}$} & \multirow{2}{*}{4} & Self & 5.33 & 4.27 & 0.36 & 51.68 & 9.78 \\
\hline & & Open & 0.51 & 1.05 & 0.10 & 9.69 & 8.91 \\
\hline \multirow{2}{*}{ Location (L) } & \multirow[b]{2}{*}{1} & Self & 1.60 & $74.29 * * *$ & $2.47^{* * *}$ & 1.59 & 25.58 \\
\hline & & Open & $249.80^{* * *}$ & $245.53 * * *$ & $15.85^{* * *}$ & $763.17 * * *$ & $1260.10^{* * *}$ \\
\hline \multirow{2}{*}{ Entry (E) } & \multirow{2}{*}{17} & Self & $29.16^{* * *}$ & $30.41^{* * *}$ & $1.38^{* * *}$ & $237.70^{* * *}$ & $65.42 * * *$ \\
\hline & & Open & $33.32 * * *$ & $11.44^{* * *}$ & $1.09 * * *$ & $135.20^{* * *}$ & $46.77^{* * *}$ \\
\hline \multirow{2}{*}{ Year (Y) } & \multirow{2}{*}{1} & Self & $244.98^{* * *}$ & $400.10^{* * *}$ & $1.10 *$ & $1780.21^{* * *}$ & $704.77^{* * *}$ \\
\hline & & Open & $24.71^{* * *}$ & $1060.63^{* * *}$ & $62.44^{* * *}$ & $3034.43^{* * *}$ & $436.82 * * *$ \\
\hline \multirow{2}{*}{$\mathrm{L} \times \mathrm{E}$} & \multirow{2}{*}{17} & Self & $21.97^{* * *}$ & $20.94^{* * *}$ & $0.81^{* * *}$ & $87.00 * * *$ & $58.69 * * *$ \\
\hline & & Open & $13.60^{* * *}$ & $13.83^{* * *}$ & $0.63^{* * *}$ & $86.05^{* * *}$ & $65.11^{* * *}$ \\
\hline \multirow{2}{*}{$\mathrm{L} \times \mathrm{Y}$} & \multirow[b]{2}{*}{1} & Self & $572.80^{* * *}$ & $34.98^{* * *}$ & $11.12^{* * *}$ & $1130.02^{* * *}$ & $137.93 * * *$ \\
\hline & & Open & $6.74^{* * *}$ & $75.21^{* * *}$ & $1.43^{* *}$ & $111.27^{* * *}$ & $156.08^{* * *}$ \\
\hline \multirow{2}{*}{$\mathrm{E} \times \mathrm{Y}$} & \multirow{2}{*}{17} & Self & $33.59^{* * *}$ & $19.39^{* * *}$ & $0.42 *$ & $234.87^{* * *}$ & $40.66^{* * *}$ \\
\hline & & Open & $26.65^{* * *}$ & $18.64^{* * *}$ & $0.53 * *$ & $158.26^{* * *}$ & $96.74^{* * *}$ \\
\hline \multirow{2}{*}{$\mathrm{L} \times \mathrm{E} \times \mathrm{Y}$} & \multirow[b]{2}{*}{17} & Self & $13.34^{* * *}$ & $6.73^{* * *}$ & $0.75^{* * *}$ & $123.43^{* * *}$ & $74.89^{* * *}$ \\
\hline & & Open & $24.20^{* * *}$ & $12.87^{* * *}$ & $0.69^{* * *}$ & $119.07^{* * *}$ & $78.21^{* * *}$ \\
\hline \multirow{2}{*}{ Residual } & \multirow{2}{*}{68} & Self & 1.71 & 1.88 & 0.21 & 14.69 & 12.32 \\
\hline & & Open & 0.71 & 2.42 & 0.24 & 14.16 & 17.30 \\
\hline \multirow{2}{*}{$\mathrm{R}^{2}$ value } & & Self & 0.96 & 0.94 & 0.84 & 0.94 & 0.86 \\
\hline & & Open & 0.98 & 0.93 & 0.87 & 0.92 & 0.86 \\
\hline
\end{tabular}

${ }^{*} p \leq 0.05 ;{ }^{* *} p \leq 0.01 ;{ }^{* * *} p \leq 0.001 ; \mathrm{df}=$ degrees of freedom; Fe = iron; $\mathrm{Zn}=$ zinc; Pa = phytic acid; Fe:Pa = molar ratio of Fe to Pa;

$\mathrm{Zn}: \mathrm{Pa}=$ molar ratio of $\mathrm{Zn}$ to $\mathrm{Pa}$. 


\section{Discussion}

The concentration of Fe and $\mathrm{Zn}$ and the molar ratio of Fe to Pa were slightly higher in self-pollinated than cross-pollinated seeds under high $\mathrm{N}$ as well as low $\mathrm{N}$ conditions. The concentration of Pa was lower in self-pollinated maize seeds under high $\mathrm{N}$ but higher under low $\mathrm{N}$ conditions. The molar ratio of $\mathrm{Zn}$ to Pa was lower in open-pollinated maize seeds under high $\mathrm{N}$ conditions while higher under low $\mathrm{N}$ conditions, indicating higher $\mathrm{Zn}$ absorption from the soil by open-pollinated seeds. A low seed set might increase seed size due to assimilate (products of photosynthesis, food) distribution into fewer grains as compared with good seed setting (open pollination). However, in this study, selfed seeds with a small size and even shrivelled seeds were also observed, indicating the additional effect of the small seed size in the high concentration of Fe and $\mathrm{Zn}$ in self-pollinated seeds [27]. The farmers' fields are deficient in $\mathrm{N}$ in western and central Africa [37]. Soil $\mathrm{N}$ leaches down to below the root zone of plants during periods of enough rainfall and results in $\mathrm{N}$ stress. Extensive removal of crop residues for animal feed and fuel, and inadequate weed control further compound soil $\mathrm{N}$ depletion $[19,38]$. Additionally, small landholder farmers apply $\mathrm{N}$ fertiliser in inadequate amounts due to the high prices of inorganic $\mathrm{N}$ fertiliser [37]. One effective strategy available for reducing fertiliser costs is to develop maize genotypes with combined high $\mathrm{N}$ use efficiency and high grain yield potential. Genotypes with high grain yield potential under low $\mathrm{N}$ are also needed to support the rapidly growing human population and provide incentives to farmers who mostly apply low to modest amounts of $\mathrm{N}$ to their maize fields. Improved maize varieties that tolerate low $\mathrm{N}$ will help maize farmers in soil $\mathrm{N}$ stress-prone areas to obtain better harvests [39]. Low $\mathrm{N}$ significantly affected the concentration and bioavailability of $\mathrm{Zn}$ in both types of hybrid seed in both seasons. During the first season, there was a large difference between the values of Fe and $\mathrm{Zn}$ in self- and open-pollinated seeds under high $\mathrm{N}$ as well as low $\mathrm{N}$ conditions. This indicated that the unknown males had a large effect on the values of Fe and $\mathrm{Zn}$. However, during the second season and in the combined seasons, there were no significant differences between the values of Fe and $\mathrm{Zn}$ in self- and open-pollinated seeds under both high $\mathrm{N}$ and low $\mathrm{N}$ conditions. This indicated that the unknown males did not influence the Fe and $\mathrm{Zn}$ concentrations in maize. Therefore, either self- or open-pollinated seeds can be used for Fe and $\mathrm{Zn}$ determination in maize. This will make it much easier, as selfing is tedious and timeconsuming. The difference in the values of $\mathrm{Fe}$ and $\mathrm{Zn}$ during the first season may have been due to dry environmental conditions. Rain was sufficient during the second season. Hybrid, location and location $\times$ hybrid effects (significant for $\mathrm{Pa}$ in the first season under low $\mathrm{N}$ ) highly significantly affected the concentrations of $\mathrm{Fe}, \mathrm{Zn}$ and $\mathrm{Pa}$, and the molar ratios of $\mathrm{Fe}$ and $\mathrm{Zn}$ to Pa in self- as well as in open-pollinated hybrids during both seasons under high $\mathrm{N}$ and low $\mathrm{N}$ conditions. Genetic differences were found for $\mathrm{Fe}, \mathrm{Zn}$ and $\mathrm{Pa}$, and the molar ratios of Fe and $\mathrm{Zn}$ to Pa among self- and open-pollinated hybrids under high $\mathrm{N}$ and low $\mathrm{N}$ conditions across locations. Highly significant hybrid (genotype) and location (environment) effects on $\mathrm{Fe}, \mathrm{Zn}$ and $\mathrm{Pa}$, and the molar ratios of $\mathrm{Fe}$ and $\mathrm{Zn}$ to Pa in maize were also reported in the literature $[40,41]$. A highly significant genotype $\times$ environment interaction effect was reported for $\mathrm{Fe}$ and $\mathrm{Zn}$ contents in the grain of 20 tropical maize genotypes [42,43], and a significant genotype $\times$ environment interaction effect was reported for Fe in the grain of 49 tropical maize varieties in six environments in Africa [29]. Breeding for tolerance to low soil $\mathrm{N}$ offers the most appropriate and sustainable approach for increased maize grain yields by small-scale farmers who apply low agricultural inputs in maize production in SSA.

\section{Conclusions}

Poor $\mathrm{N}$ significantly affected the concentration and bioavailability of zinc during both seasons. Environment played a crucial role in the expression of Fe and $\mathrm{Zn}$ in maize. Unknown males had no significant influence on Fe and Zn concentrations in maize when measured over two seasons. Therefore, maize breeders can use open-pollinated seeds for Fe and Zn determination in maize in future. This will make it much easier, as selfing is tedious and time-consuming. 
Supplementary Materials: The following are available online at https://www.mdpi.com/article/10 .3390 /agronomy11071388/s1. Table S1. Mean performance for Fe, Zn and Pa, and the molar ratios of $\mathrm{Fe}$ and $\mathrm{Zn}$ to Pa in self- and open-pollinated maize seeds under high $\mathrm{N}$ conditions during Season 1. Table S2. Analysis of variance showing the mean squares for $\mathrm{Fe}, \mathrm{Zn}$ and $\mathrm{Pa}$, and molar ratios of Fe and $\mathrm{Zn}$ to Pa in self- and open-pollinated maize seeds under high $\mathrm{N}$ conditions during Season 1. Table S3. Mean performance for Fe, $\mathrm{Zn}$ and $\mathrm{Pa}$, and the molar ratios of Fe and $\mathrm{Zn}$ to Pa in self- and open-pollinated maize seeds under low $\mathrm{N}$ conditions during Season 1. Table S4. Analysis of variance showing the mean squares for $\mathrm{Fe}, \mathrm{Zn}$ and $\mathrm{Pa}$ and the molar ratios of $\mathrm{Fe}$ and $\mathrm{Zn}$ to Pa in self- and open-pollinated maize seeds under low $\mathrm{N}$ conditions during Season 1. Table S5. Mean performance for $\mathrm{Fe}, \mathrm{Zn}$ and $\mathrm{Pa}$, and the molar ratios of $\mathrm{Fe}$ and $\mathrm{Zn}$ to $\mathrm{Pa}$ in self- and open-pollinated maize seeds under high $\mathrm{N}$ conditions during Season 2. Table S6. Analysis of variance showing the mean squares for $\mathrm{Fe}, \mathrm{Zn}$ and $\mathrm{Pa}$, and molar ratios of $\mathrm{Fe}$ and $\mathrm{Zn}$ to $\mathrm{Pa}$ in self- and open-pollinated maize seeds under high $\mathrm{N}$ conditions during Season 2. Table S7. Mean performance for $\mathrm{Fe}, \mathrm{Zn}$ and $\mathrm{Pa}$, and the molar ratios of $\mathrm{Fe}$ and $\mathrm{Zn}$ to $\mathrm{Pa}$ in self- and open-pollinated maize seeds under low $\mathrm{N}$ conditions during Season 2. Table S8. Analysis of variance showing the mean squares for $\mathrm{Fe}, \mathrm{Zn}$ and $\mathrm{Pa}$, and the molar ratios of Fe and $\mathrm{Zn}$ to $\mathrm{Pa}$ in self- and open-pollinated maize seeds under low $\mathrm{N}$ conditions during Season 2.

Author Contributions: Conceptualisation, S.A., M.L. and K.M.; methodology, S.A.; software, S.A., A.H. and M.L.; validation, M.L. and G.O.; formal analysis, S.A., A.H. and M.L.; investigation, S.A.; resources, M.L. and K.M.; data curation, S.A., M.L. and K.M.; writing-original draft preparation, S.A. and M.L.; writing—review and editing, M.L., G.O., A.H. and K.M.; visualisation, M.L., G.O. and K.M.; supervision, M.L., G.O. and K.M.; project administration, S.A.; funding, M.L., G.O. and K.M. All authors have read and agreed to the published version of the manuscript.

Funding: The current research work was funded by the National Research Foundation (NRF), South Africa, and The World Academy of Sciences (TWAS), Italy.

Institutional Review Board Statement: Not applicable.

Informed Consent Statement: Not applicable.

Data Availability Statement: Most of the recorded data are available in all the tables in the manuscript.

Acknowledgments: The authors sincerely acknowledge the contributions of NRF, South Africa, and TWAS, Italy, for providing the research funds to complete this project. The author acknowledges the soil science laboratory for providing support for the Fe and $\mathrm{Zn}$ analyses, and the Grain Crops Institute, Agricultural Research Council (GCI-ARC) for providing labour and research stations for conducting the research experiments.

Conflicts of Interest: The authors would hereby like to declare that there is no conflict of interest.

\section{References}

1. Edmeades, G.O.; Trevisan, W.; Prasanna, B.M.; Campos, H. Tropical maize (Zea mays L.). In Genetic Improvement of Tropical Crops; Campos, H., Caligari, P.D.S., Eds.; Springer: Cham, Switzerland, 2017; pp. 57-109. [CrossRef]

2. Tajwar, T.; Chakraborty, M. Combining ability and heterosis for grain yield and its components in maize inbreds over environments (Zea mays L.). Afr. J. Agric. Res. 2013, 8, 3276-3290.

3. Chomba, E.; Westcott, C.M.; Westcott, J.E.; Mpabalwani, E.M.; Krebs, N.F.; Patinkin, Z.W.; Palacios, N.; Hambidge, K.M. Zinc absorption from biofortified maize meets the requirements of young rural Zambian children. J. Nutr. 2015, 145, 514-519. [CrossRef]

4. De Groote, H.; Dema, G.; Sonda, G.; Gitonga, Z. Maize for food and feed in East Africa -The farmers' perspective. Field Crops Res. 2013, 153, 22-36. [CrossRef]

5. Mathenge, M.K.; Smale, M.; Olwande, J. The impacts of hybrid maize seed on the welfare of farming households in Kenya. Food Policy 2014, 44, 262-271. [CrossRef]

6. Ureta, C.; González-Salazar, C.; González, E.J.; Álvarez-Buylla, E.R.; Martínez-Meyer, E. Environmental and social factors account for Mexican maize richness and distribution: A data mining approach. Agric. Ecosyst. Environ. 2013, 179, 25-34. [CrossRef]

7. Stewart, C.P.; Dewey, K.G.; Ashorn, P. The undernutrition epidemic: An urgent health priority. Lancet 2010, 375, 282. [CrossRef]

8. Welch, R.M.; Graham, R.D. Breeding for micronutrients in staple food crops from a human nutrition perspective. J. Exp. Bot. 2004, 55, 353-364. [CrossRef] [PubMed]

9. Misra, B.K.; Sharma, R.K.; Nagarajan, S. Plant breeding: A component of public health strategy. Curr. Sci. 2004, 86, 1210-1215.

10. Bouis, H.E. Plant breeding: A new tool for fighting micronutrient malnutrition. J. Nutr. 2002, 132, 491S-494S. [CrossRef] [PubMed] 
11. Frossard, E.; Bucher, M.; Buchler, F.; Mozafar, A.; Hurrell, R. Potential for increasing the content and bioavailability of Fe, Zn and Ca in plants for human nutrition. J. Sci. Food Agric. 2000, 80, 861-879. [CrossRef]

12. Fageria, N.K.; Moraes, M.F.; Ferreira, E.P.B.; Knupp, A.M. Biofortification of trace elements in food crops for human health. Commun. Soil Sci. Plant Anal. 2012, 43, 556-570. [CrossRef]

13. Babu, R.; Palacios, N.; Prasanna, B. Biofortified maize-A genetic avenue for nutritionalsecurity. In Translational Genomics for Crop Breeding: Abiotic Stress, Yield and Quality; Varshney, R.K., Tuberosa, R., Eds.; John Wiley \& Sons: Hoboken, NJ, USA, 2013; pp. 161-176.

14. Gibson, R.S. Zinc deficiency and human health: Etiology, health consequences, and future solutions. Plant Soil 2012, 361, 291-299. [CrossRef]

15. Bouis, H.E.; Saltzman, A. Improving nutrition through biofortification: A review of evidence from HarvestPlus, 2003 through 2016. Glob. Food Sec. 2017, 12, 49-58. [CrossRef]

16. Pujar, M.; Govindaraj, M.; Gangaprasad, S.; Kanatti, A.; Shivade, H. Genetic variation and diversity for grain iron, zinc, protein and agronomic traits in advanced breeding lines of pearl millet [Pennisetum glaucum (L.) R. Br.] for biofortification breeding. Genet. Resour. Crop Evol. 2020, 67, 2009-2022. [CrossRef]

17. White, P.J.; Broadley, M.R. Biofortification of crops with seven mineral elements often lacking in human diets-Iron, zinc, copper, calcium, magnesium, selenium and iodine. New Phyt. 2009, 182, 49-84. [CrossRef]

18. Zangani, E.; Afsahi, K.; Shekari, F.; Mac Sweeney, E.; Mastinu, A. Nitrogen and Phosphorus Addition to Soil Improves Seed Yield, Foliar Stomatal Conductance, and the Photosynthetic Response of Rapeseed (Brassica napus L.). Agriculture 2021, 11, 483. [CrossRef]

19. Noëlle, M.A.H.; Richard, K.; Vernon, G.; Martin, Y.A.; Laouali, M.N.; Liliane, T.N.; Godswill, N.N. Combining ability and gene action of tropical maize (Zea mays L.) inbred lines under low and high nitrogen conditions. J. Agric. Sci. 2017, 9, $222-235$. [CrossRef]

20. Ige, S.A.; Bello, O.B.; Alake, O. Combining ability and heterosis of tolerance to low soil nitrogen in tropical maize cultivars derived from two breeding eras. Open Agric. 2018, 3, 339-347. [CrossRef]

21. Bänzinger, M.; Edmeades, G.O.; Beck, D.; Bellon, M. Breeding for Drought and Nitrogen Stress Tolerance in Maize from Theory to Practice; International Maize and Wheat Improvement Center (CIMMYT), CIMMYT: Texcoco, México, 2000; Available online: https:/ / repository.cimmyt.org/bitstream/handle/10883/765/68579.pdf?sequence=1\&isAllowed=y (accessed on 20 May 2021).

22. Pfeiffer, W.H.; McClafferty, B. HarvestPlus: Breeding crops for better nutrition. Crop Sci. 2007, 47, S88-S105. [CrossRef]

23. Hindu, V.; Palacios-Rojas, N.; Raman, B.; Suwarno, W.; Rashid, Z.; Usha, R.; Gajanan, S.R.; Nair, S. Identification and validation of genomic regions influencing kernel zinc and iron in maize. Theor. Appl. Genet. 2018, 131, 1443-1457. [CrossRef]

24. Bulant, C.; Gallais, A.; Matthys-Rochon, E.; Prioul, J.L. Xenia effects in maize with normal endosperm. Crop Sci. 2000, 40, 182-189. [CrossRef]

25. Burton, G. The immediate effect of gametic relationship upon seed production in pearl millet, Pennisetum glaucum. Agron. J. 1952, 44, 424. [CrossRef]

26. Burton, G.W.; Rabson, R.; Axmann, H. Immediate effect of male and female gametes and N on five pearl millet grain characteristics. Crop Sci. 1980, 20, 7-9. [CrossRef]

27. Rai, K.N.; Govindaraj, M.; Pfeiffer, W.H.; Rao, A.S. Seed set and xenia effects on grain iron and zinc density in pearl millet. Crop Sci. 2015, 55, 821-827. [CrossRef]

28. Oikeh, S.O.; Menkir, A.; Maziya-Dixon, B.; Welch, R.; Glahn, R.P. Assessment of concentrations of iron and zinc and bioavailable iron in grains of early-maturing tropical maize varieties. J. Agric. Food Chem. 2003, 51, 3688-3694. [CrossRef] [PubMed]

29. Oikeh, S.O.; Menkir, A.; Maziya-Dixon, B.; Welch, R.; Glahn, R.P. Genotypic differences in concentration and bioavailability of kernel-iron in tropical maize varieties grown under field conditions. J. Plant Nutr. 2003, 26, 2307-2319. [CrossRef]

30. Ndhlela, T. Improvement Strategies for Yield Potential, Disease Resistance and Drought Tolerance of Zimbabwean Maize Inbred Lines. Ph.D. Thesis, University of the Free State, Bloemfontein, South Africa, 2012.

31. AOAC Official Methods of Analysis. Official Methods 985.01, 17th ed.; The Association of Official Analytical Chemists: Gaithersburg, MD, USA, 2000; Volume 1.

32. Dragičević, V.; Sredojević, S.; Peric, V.; Nisavic, A.; Srebric, M. Validation study of a rapid colorimetric method for the determination of phytic acid and inorganic phosphorus from seeds. Acta Period. Technol. 2011, 42, 11-21. [CrossRef]

33. Latta, M.; Eskin, M.A. Simple and rapid colorimetric method for phytate determination. J. Agric. Food Chem. 1980, $28,1313-1315$. [CrossRef]

34. Norhaizan, M.; Nor Faizadatul Ain, A.W. Determination of phytate, iron, zinc, calcium contents and their molar ratios in commonly consumed raw and prepared food in malaysia. Malas. J. Nutr. 2009, 15, 213-222.

35. Dorsey-Redding, C.; Hurburgh, C.R., Jr.; Johnson, L.A.; Fox, S.R. Adjustment of maize quality data for moisture content. Cereal Chem. 1990, 67, 292-295.

36. Agrobase. Agrobase Generation II User's Manual, revised ed.; Agronomix software Inc.: Winnipeg, MB, Canada, 2017; Available online: www.agronomix.com (accessed on 1 March 2021).

37. Bello, O.B.; Olawuyi, O.J.; Lawal, M.; Ige, S.A.; Mahamood, J.; Afolabi, M.S.; Azeez, M.A.; Abdulmaliq, S.Y. Genetic gains in three breeding eras of maize hybrids under low and optimum nitrogen fertilization. J. Agric. Sci. 2014, 59, 227-242. [CrossRef] 
38. Zambezi, B.T.; Mwambula, C. The impact of drought and low soil nitrogen on maize production in the SADC region. In Developing Drought and Lown N Tolerant Maize; Edmeades, G., Bänziger, M., Mickelson, H., Peña-Valdivia, C., Eds.; CIMMYT: Texcoco, México, 1997; pp. 29-34.

39. Zaidi, P.H.; Rafique, S.; Singh, N.N. Response of maize (Zea mays L.) genotypes to excess soil moisture stress: Morpho-physiological effects and basis of tolerance. Eur. J. Agron. 2003, 19, 383-399. [CrossRef]

40. Šimić, D.; Sudar, R.; Ledenčan, T.; Jambrović, A.; Zdunić, Z.; Brkić, I.; Kovačević, V. Genetic variation of bioavailable iron and zinc in grain of a maize population. J. Cereal Sci. 2009, 50, 392-397. [CrossRef]

41. Šimić, D.; Drinic, S.M.; Zdunic, Z.; Jambrovic, A.; Ledencan, T.; Brkic, J.; Brkic, A.; Brkic, I. Quantitative trait loci for biofortification traits in maize grain. J. Hered. 2011, 103, 47-54. [CrossRef] [PubMed]

42. Oikeh, S.O.; Menkir, A.; Maziya-Dixon, B.; Welch, R.M.; Glahn, R.P.; Gauch, G. Environmental stability of iron and zinc concentrations in grain of elite early-maturing tropical maize genotypes grown under field conditions. J. Agric. Sci. 2004, 142, 543-551. [CrossRef]

43. Bello, O.; Afolabi, M.; Ige, S.; Abdulmaliq, S.; Azeez, M.; Mahmud, J. Yield response of diallelic crossed maize (Zea mays L.) genotypes to varying nitrogen regimes in Nigeria. J. Bio-Sci. 2011, 19, 43-52. [CrossRef] 